\title{
Detection of adamantane-sensitive influenza A(H3N2) viruses in Australia, 2017: a cause for hope?
}

Aeron Hurt' ${ }^{1,2}$, Naomi Komadina1, Yi-Mo Deng ${ }^{1}$, Matthew Kaye ${ }^{1}$, Sheena Sullivan ${ }^{1,3}$, Kanta Subbarao ${ }^{1,2}$, Ian Barr ${ }^{1,2}$

1. WHO Collaborating Centre for Reference and Research on Influenza, The Peter Doherty Institute for Infection and Immunity, Melbourne, Victoria, Australia

2. Department of Microbiology and Immunology, The University of Melbourne, The Peter Doherty Institute for Infection and Immunity, Melbourne, Victoria, Australia

3. School of Global and Population Health, The University of Melbourne, Victoria, Australia

Correspondence: Aeron Hurt (aeron.hurt@influenzacentre.org)

Citation style for this article:

Hurt Aeron, Komadina Naomi, Deng Yi-Mo, Kaye Matthew, Sullivan Sheena, Subbarao Kanta, Barr lan. Detection of adamantane-sensitive influenza A(H3N2) viruses in Australia, 2017: a cause for hope?. Euro Surveill. 2017;22(47):pii=17-00731. https://doi.org/10.2807/1560-7917.ES.2017.22.47.17-00731

For over a decade virtually all $\mathrm{A}\left(\mathrm{H}_{3} \mathrm{~N}_{2}\right)$ influenza viruses have been resistant to the adamantane class of antivirals. However, during the 2017 influenza season in Australia, 15/461 (3.3\%) adamantane-sensitive $\mathrm{A}\left(\mathrm{H}_{3} \mathrm{~N}_{2}\right)$ viruses encoding serine at residue 31 of the M2 protein were detected, more than the total number identified globally during the last 6 years. A return to wide circulation of adamantane-sensitive $A\left(\mathrm{H}_{3} \mathrm{~N}_{2}\right)$ viruses would revive the option of using these drugs for treatment and prophylaxis.

Amantadine and rimantadine are compounds of the adamantane class of antivirals which act on influenza A viruses by binding to the $\mathrm{M}_{2}$ ion channel, preventing uncoating of the virus during replication. Treatment of influenza A virus infection with these drugs within 48 hours of symptom onset reduces illness by ca 24 hours, and when given prophylactically, the drugs can prevent ca $60 \%$ of influenza cases [1]. However, effectiveness of both drugs is lost when viruses acquire an amino acid substitution at one of five critical residues of the $M_{2}$ protein i.e. positions $26,27,30,31$ and 34 [2]. The occurrence of adamantane-resistant influenza A viruses was rare among circulating influenza viruses [3] until 2000, when an increasing proportion of viruses from Asia, particularly China, contained the serine (S) to asparagine $(\mathrm{N})$ substitution at residue $31\left(\mathrm{~S}_{31} \mathrm{~N}\right)$ of the $M_{2}$ protein [4]. By the end of the 2005/06 influenza season, over $90 \%$ of circulating $\mathrm{A}\left(\mathrm{H}_{3} \mathrm{~N}_{2}\right)$ viruses in North America and other parts of the northern hemisphere, such as Asia, contained the $\mathrm{S}_{31} \mathrm{~N}$ substitution even though the vast majority of resistant viruses were from patients who had not been treated with adamantanes [5]. After more than 7 years of almost complete dominance of adamantane-resistant $A\left(\mathrm{H}_{3} \mathrm{~N}_{2}\right)$ influenza viruses globally, we describe the detection in Australia of increased numbers of adamantane-sensitive viruses during the 2017 influenza season.

\section{Global frequency of adamantane-resistant} $\mathrm{A}(\mathrm{H} 3 \mathrm{~N} 2)$ viruses $1968-2017$

Analysis of all $M_{2}$ gene sequences of $A\left(H_{3} N_{2}\right)$ viruses deposited in the EpiFlu public sequence database of the Global Initiative on Sharing All Influenza Data (GISAID) $(n=26,231$; as at 21 November 2017), showed that the global frequency of adamantane-resistant $\mathrm{A}\left(\mathrm{H}_{3} \mathrm{~N}_{2}\right)$ viruses with $\mathrm{M}_{2} \mathrm{~N}_{31}$ has been >99\% each year from 2010 to 2017 (Table 1).

\section{Analysis of the adamantane-resistance situation in Australia during the 2017 influenza season}

The Australian 2017 influenza season was dominated by high levels of $\mathrm{A}\left(\mathrm{H}_{3} \mathrm{~N}_{2}\right)$ influenza virus activity. During this season, 15 adamantane-sensitive $A\left(\mathrm{H}_{3} \mathrm{~N}_{2}\right)$ viruses encoding $\mathrm{M}_{2} \mathrm{~S}_{31}$ were detected in Australia (Table 2), which exceeded the cumulative total of 11 adamantane-sensitive influenza A viruses detected globally between 2011 and 2016 (Table 1). In contrast, the frequency of adamantane-resistance in circulating $\mathrm{A}\left(\mathrm{H}_{1} \mathrm{~N}_{1}\right)$ pdmog viruses has remained unchanged at $>99.9 \%$ both in Australia and worldwide.

Using Sanger sequencing [6], next generation sequencing [7] or pyrosequencing [8] we found that from 1 March to 30 June 2017, all 310 tested Australian $\mathrm{A}\left(\mathrm{H}_{3} \mathrm{~N}_{2}\right)$ viruses encoded $\mathrm{M}_{2} \mathrm{~N}_{31}$ indicating adamantane-resistance (M2 N31 viruses). However, in July, August and September 2017 , two of 201 (1.0\%), 10 of $115(8.7 \%)$ and three of $145(2.1 \%)$ tested $\mathrm{A}\left(\mathrm{H}_{3} \mathrm{~N}_{2}\right)$ virus isolates, respectively, encoded $\mathrm{M}_{2} \mathrm{~S}_{31}$ indicating adamantanesensitivity ( $M_{2} S_{31}$ viruses). The $M_{2} S_{31}$ viruses were detected across four states in Australia (Victoria: $n=10$; New South Wales: $n=2$; Queensland: $n=2$; Northern Territory: $n=1$ ), as well as 1 of 70 tested from New Zealand (Figure 1), indicating that although overall frequency was low, the M2 S31 viruses had spread across a large geographic area (Table 2). $\mathrm{A}\left(\mathrm{H}_{3} \mathrm{~N}_{2}\right)$ influenza viruses tested from the other Australian states of 


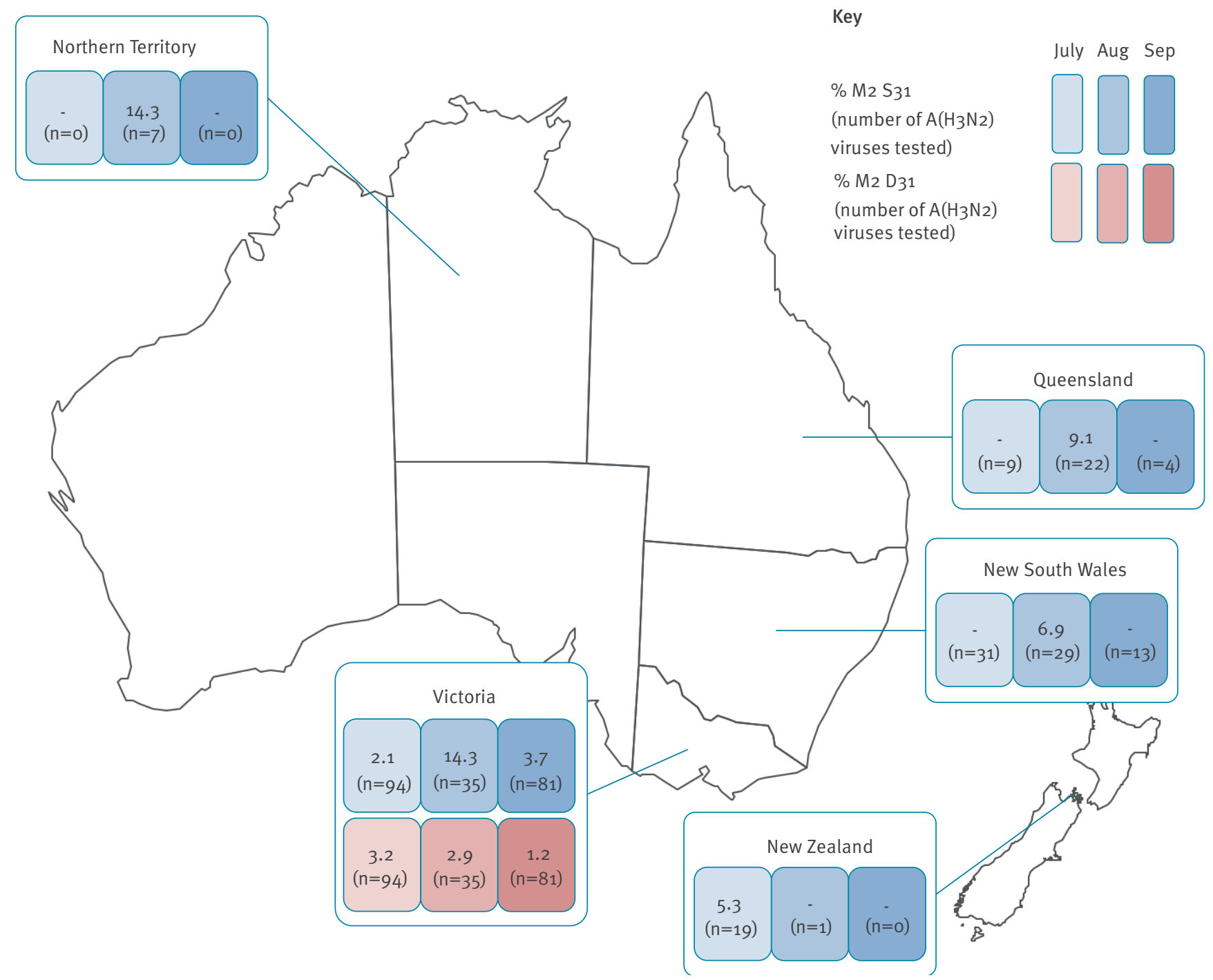

No M2 331 or M2 D31 viruses were detected in the states of South Australia, Western Australia, Tasmania or the Australian Capital Territory where the number of influenza $A\left(\mathrm{H}_{3} \mathrm{~N}_{2}\right)$ viruses tested was $149,40,52$ and 32, respectively.

South Australia $(n=148)$, Western Australia $(n=40)$, Tasmania $(n=54)$ and the Australian Capital Territory $(n=32)$ were all $M_{2} N_{31}$ viruses.

In Victoria, M2 S31 viruses were detected in July, August and September, with the peak detection frequency of five of 35 occurring in August (Figure 1). In addition to the $10 \mathrm{M}_{2} \mathrm{~S}_{31}$ viruses, a further five Victorian $\mathrm{A}\left(\mathrm{H}_{3} \mathrm{~N}_{2}\right)$ viruses contained an alternative amino acid, aspartic acid (D), at residue 31 of the $M_{2}$ protein (M2 $D_{31}$ viruses) (Figure 1)(Table 2). M2 D31 viruses have been extremely rare since the emergence of the $A\left(\mathrm{H}_{3} \mathrm{~N}_{2}\right)$ viruses in 1968, with just 11 of 21,064 (0.05\%) viruses detected globally before 2017, compared with the detection rate of five of $210(2.4 \%)$ seen between July and September 2017 in Victoria (Figure 1). However, M2 D31 viruses remain adamantane-resistant [9]. Original specimens were available for eight of the $\mathrm{M}_{2} \mathrm{~S}_{31}$ or D31 virus isolates, and sequencing confirmed $100 \% \mathrm{nt}$ match between the isolates/clinical specimen pairs, with no evidence of mixed viral populations at the codon for position 31 of the M2 protein.

\section{Phylogenetic analysis of Australian M2 S31 influenza $\mathrm{A}(\mathrm{H} 3 \mathrm{~N} 2)$ viruses}

To understand whether the $M_{2} S_{31}$ or $D_{31}$ viruses emerged from a single source or occurred sporadically, phylogenetic trees were constructed using the haemagglutinin ( $\mathrm{HA}$ ), neuraminidase (NA) and $\mathrm{M}_{2}$ gene sequences of the $2017 \mathrm{~A}\left(\mathrm{H}_{3} \mathrm{~N}_{2}\right)$ viruses from Australia, together with global $A\left(\mathrm{H}_{3} \mathrm{~N}_{2}\right)$ virus sequences from March to September 2017 available from GISAID (Figure 2 , Figure 3 and Figure 4). The authors acknowledge the originating and submitting laboratories that provided 


\section{FIGURE 2}

Phylogenetic tree of influenza $\mathrm{A}(\mathrm{H} 3 \mathrm{~N} 2)$ virus haemagglutinin sequences

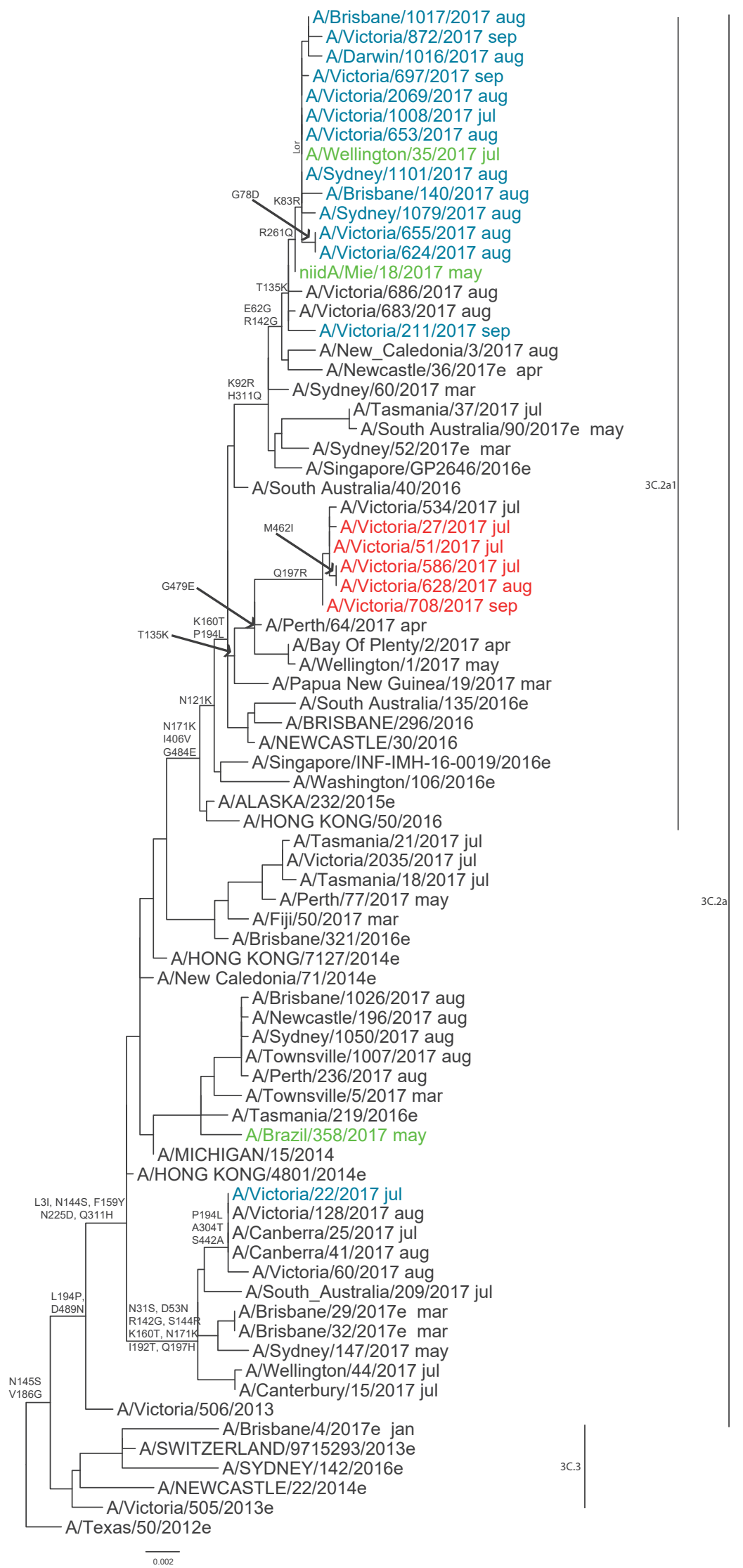

Australian M2 S31 viruses are coloured in blue, non-Australian M2 S31 viruses are coloured in green, and Australian M2 D31 viruses are coloured in red. All other viruses contain the $\mathrm{N}_{31}$ in the $\mathrm{M}_{2}$ protein. GISAID ID numbers for the $\mathrm{M}_{2} \mathrm{~S}_{3} 1$ and $\mathrm{D}_{3} 1$ virus sequences are listed in Table 2.

The sequence data were aligned using the MAFT algorithm in Geneious V10.0.09 (Biomatters Ltd, Auckland, New Zealand). Maximum likelihood phylogenetic trees were generated with RAxML v8.2, using nucleotide substitution models. Amino acid substitutions were calculated using BASEML within PAML 4.9e with FigTree v1.4.3 used to project amino acid substitutions onto the phylogenetic trees. 


\section{FIGURE 3}

Phylogenetic tree of influenza A(H3N2) virus neuraminidase sequences

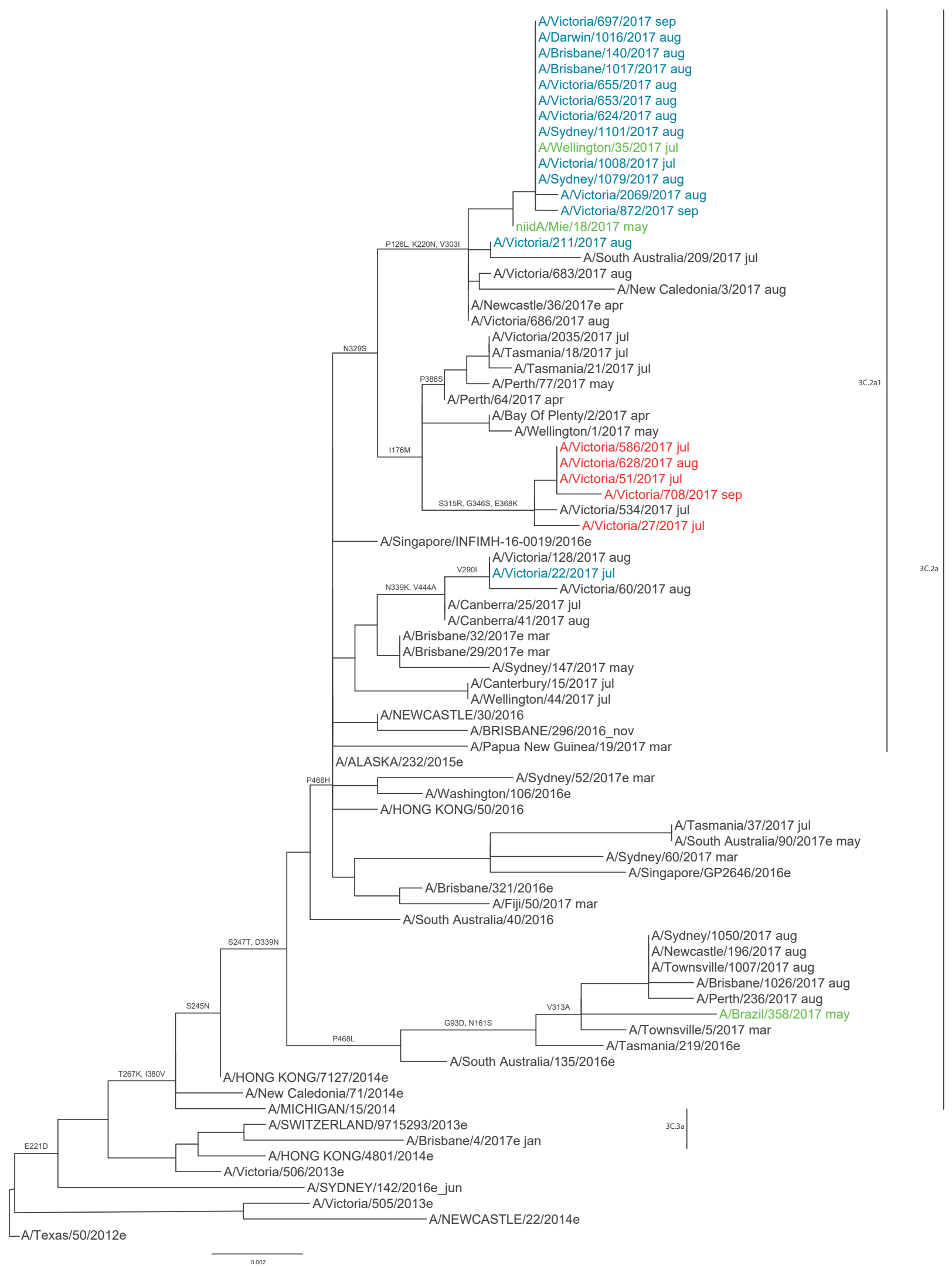

Australian M2 S31 viruses are coloured in blue, non-Australian M2 S31 viruses are coloured in green, and Australian M2 D31 viruses are coloured in red. All other viruses contain the $N_{31}$ in the $M_{2}$ protein. GISAID ID numbers for the $M_{2} S_{31}$ and $D_{31}$ virus sequences are listed in Table 2. The sequence data were aligned using the MAFT algorithm in Geneious V10.0.09 (Biomatters Ltd, Auckland, New Zealand). Maximum likelihood phylogenetic trees were generated with RAxML v8.2, using nucleotide substitution models. Amino acid substitutions were calculated using BASEML within PAML 4.9e with FigTree v1.4.3 used to project amino acid substitutions onto the phylogenetic trees. 


\section{FIGURE 4}

Phylogenetic tree of influenza A(H3N2) virus M2 sequences

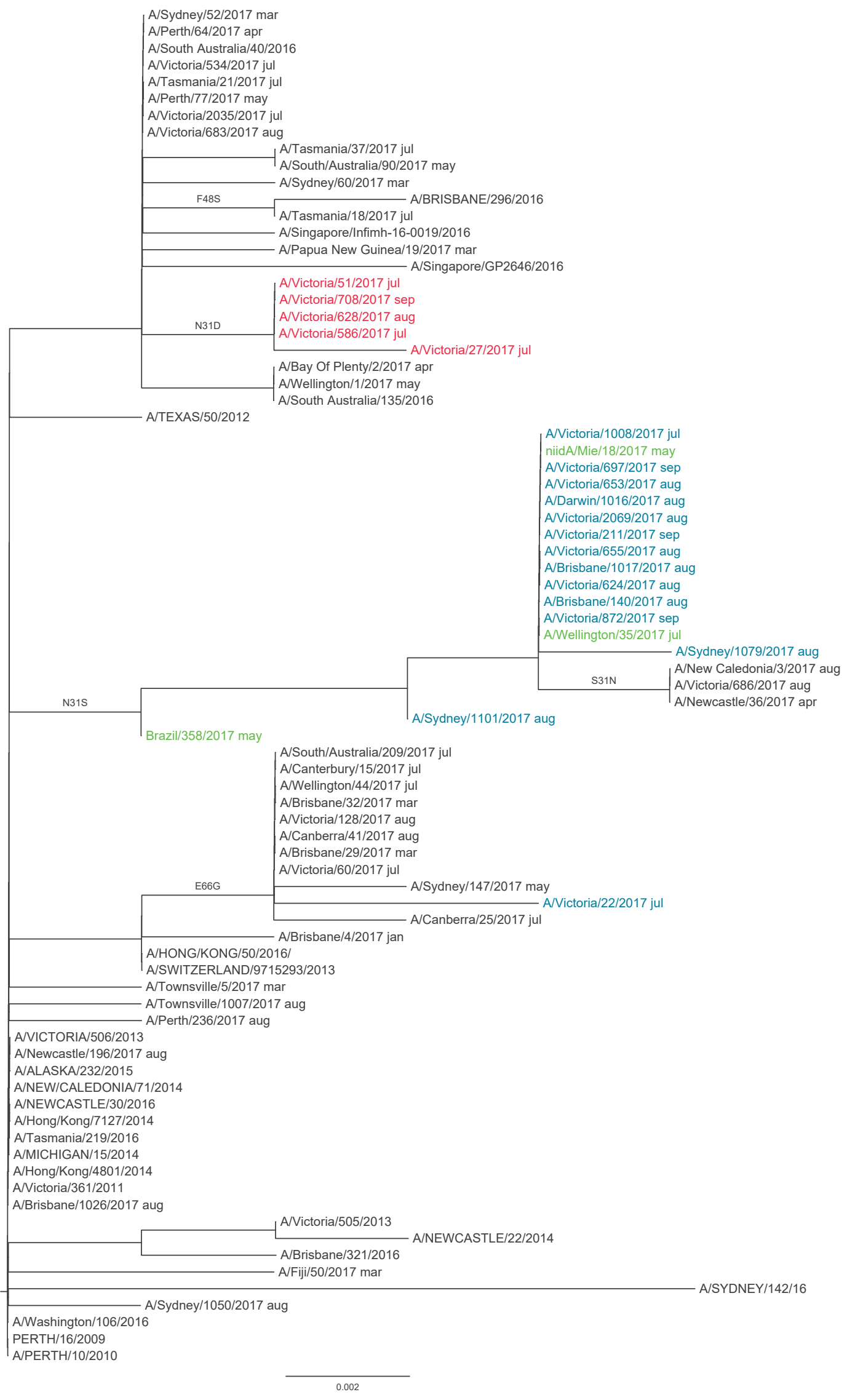

Australian M2 S31 viruses are coloured in blue, non-Australian M2 S31 viruses are coloured in green, and Australian M2 D31 viruses are coloured in red. All other viruses contain the $\mathrm{N}_{31}$ in the $\mathrm{M}_{2}$ protein. GISAID ID numbers for the $\mathrm{M}_{2} \mathrm{~S}_{31}$ and $\mathrm{D}_{31}$ virus sequences are listed in Table 2. The sequence data were aligned using the MAFT algorithm in Geneious V10.0.09 (Biomatters Ltd, Auckland, New Zealand). Maximum likelihood phylogenetic trees were generated with RAxML v8.2, using nucleotide substitution models. Amino acid substitutions were calculated using BASEML within PAML 4.9e with FigTree v1.4.3 used to project amino acid substitutions onto the phylogenetic trees. 
TABLE 1

Frequency of influenza A(H3N2) viruses with different amino acids at residue 31 of the M2 protein, 1968-2017

\begin{tabular}{|c|c|c|c|c|c|c|}
\hline \multirow[t]{2}{*}{ Year(s) } & \multicolumn{2}{|c|}{$\begin{array}{c}\text { M2 S31 } \\
\text { (adamantane-sensitive) }\end{array}$} & \multicolumn{2}{|c|}{$\begin{array}{c}\text { M2 } \mathrm{N}_{31} \\
\text { (adamantane-resistant) }\end{array}$} & \multicolumn{2}{|c|}{$\begin{array}{c}\text { M2 D31 } \\
\text { (adamantane-resistant) }\end{array}$} \\
\hline & $\mathrm{n}$ & $\%$ & $\mathrm{n}$ & $\%$ & $\mathrm{n}$ & $\%$ \\
\hline 1968-1999 & 1,153 & 98.3 & 20 & 1.7 & 0 & 0.0 \\
\hline 2000 & 224 & 99.1 & 2 & 0.9 & 0 & 0.0 \\
\hline 2001 & 112 & 99.1 & 1 & 0.9 & 0 & 0.0 \\
\hline 2002 & 304 & 99.0 & 3 & 1.0 & 0 & 0.0 \\
\hline 2003 & 424 & 87.8 & 59 & 12.2 & 0 & 0.0 \\
\hline $2004^{b}$ & 341 & $77 \cdot 5$ & 98 & 22.3 & 0 & 0.0 \\
\hline 2005 & 229 & 45.1 & 279 & $54 \cdot 9$ & 0 & 0.0 \\
\hline 2006 & 38 & 13.0 & 254 & 87.0 & 0 & 0.0 \\
\hline 2007 & 85 & 12.6 & 589 & 87.0 & 3 & 0.4 \\
\hline 2008 & 7 & 1.2 & 597 & 98.8 & 0 & 0.0 \\
\hline 2009 & 11 & 1.1 & 948 & 98.9 & 0 & 0.0 \\
\hline 2010 & 9 & 0.9 & 973 & 99.1 & 0 & 0.0 \\
\hline 2011 & 3 & 0.2 & 1,307 & 99.7 & 1 & 0.1 \\
\hline 2012 & 3 & 0.2 & 1,897 & 99.8 & 0 & 0.0 \\
\hline 2013 & 0 & 0.0 & 1,445 & 100.0 & 0 & 0.0 \\
\hline 2014 & 2 & 0.1 & 1,892 & 99.6 & 5 & 0.3 \\
\hline 2015 & 2 & 0.1 & 3,454 & 99.9 & 1 & $<0.1$ \\
\hline 2016 & 1 & $<0.1$ & 4,286 & $>99.9$ & 1 & $<0.1$ \\
\hline $2017^{c}$ & 20 & 0.4 & 5,142 & 99.5 & 5 & 0.1 \\
\hline
\end{tabular}

as at 21 November 2017.

b One virus with $\mathrm{M}_{2}$ I31 was detected.

'Includes the Australian viruses reported in this study.

Percentages rounded to one decimal.

The authors acknowledge the originating and submitting laboratories that provided sequences to GISAID's EpiFlu database which were used to calculate the global frequencies of $\mathrm{A}\left(\mathrm{H}_{3} \mathrm{~N}_{2}\right)$ viruses with different amino acid residues at position 31 of the M2 (www.gisaid.org).

sequences to GISAID's EpiFlu database which were used to construct the phylogenetic trees (www.gisaid. org). In both HA and NA phylogenetic trees all but two of the Australian M2 S31 viruses formed a monophyletic group, together with a Japanese and New Zealand M2 S31 virus. The Japanese virus, A/Mie/18/2017 (isolated in May 2017), was positioned ancestrally to the $M_{2} S_{31}$ Australian viruses in both the HA and NA clades (Figure 2 and Figure 3), suggesting it may have been the progenitor. All of the $M_{2} S_{31}$ viruses were part of the HA clade 3 C.2a1, except for one strain (A/ Victoria/22/2017) from July which was a 3 C.2a virus (Figure 2), and all but one (A/Victoria/211/2017) of the 3C.2a1 viruses formed the subclade characterised by HA amino acid substitutions R261Q and K83R (Figure 2), which exclusively contained these viruses even when all $A\left(\mathrm{H}_{3} \mathrm{~N}_{2}\right)$ viruses via GISAID were included in the analysis. The M2 D31 viruses clustered together phylogenetically, forming a separate branch within the HA clade 3C.2a1, although this clade also contained some M2 N31 Australian viruses (Figure 2).

\section{Discussion and conclusion}

Adamantane-resistance was first detected in persons infected with influenza virus who were treated with adamantanes in the late 1980s, in closed settings, such as nursing homes $[10,11]$, as well as community settings [12]. In the latter, there was apparent transmission of drug-resistant strains, when rimantadine was used for treatment or post-exposure prophylaxis in families [12]. Adamantane-resistant viruses were also detected in nursing home patients without exposure to these drugs [13], demonstrating that adamantaneresistant variants may be able to spread in the community. Up to $45 \%$ of children treated with rimantadine have been reported to shed resistant viruses [14]. In addition to widespread adamantane-resistance among $\mathrm{A}\left(\mathrm{H}_{3} \mathrm{~N}_{2}\right)$ influenza viruses circulating globally, seasonal influenza $A\left(\mathrm{H}_{1} \mathrm{~N}_{1}\right)$ viruses also developed adamantane-resistance between 2005 and 2008 [15,16], and the $\mathrm{A}\left(\mathrm{H}_{1} \mathrm{~N}_{1}\right)$ pdmog virus that emerged and caused the influenza pandemic in 2009 was also adamantaneresistant. As consequence of these developments, adamantanes are no longer recommended for treatment of influenza [5]. 
TABLE 2

Details of M2 S31 and D31 influenza A(H3N2) viruses detected in Australia and New Zealand, July -September 2017 (n=21)

\begin{tabular}{|c|c|c|c|c|c|c|c|}
\hline Virus designation & Location & $\begin{array}{c}\text { Specimen } \\
\text { date } \\
\text { (2017) }\end{array}$ & $\begin{array}{l}\text { M2 } 31 \\
\text { residue }\end{array}$ & Age (years) & Sex & $\begin{array}{l}\text { Patient } \\
\text { status }\end{array}$ & GISAID isolate ID \\
\hline A/Wellington/35/2017 & Wellington, New Zealand & $3 \mathrm{Jul}$ & $\mathrm{S}$ & Unknown & Female & Out-patient & EPI_ISL_277612 \\
\hline A/Victoria/27/2017 & Victoria, Australia & $3 \mathrm{Jul}$ & $\mathrm{D}$ & 20 & Female & Unknown & EPI_ISL_277591 \\
\hline A/Victoria/22/2017 & Victoria, Australia & $4 \mathrm{Jul}$ & $\mathrm{S}$ & 21 & Female & Unknown & EPI_ISL_275249 \\
\hline A/Victoria/1008/2017 & Victoria, Australia & $18 \mathrm{Jul}$ & $\mathrm{S}$ & 27 & Male & Unknown & EPI_ISL_277586 \\
\hline A/Victoria/51/2017 & Victoria, Australia & $18 \mathrm{Jul}$ & $\mathrm{D}$ & 77 & Male & Unknown & EPI_ISL_277338 \\
\hline A/Victoria/586/2017 & Victoria, Australia & $21 \mathrm{Jul}$ & $\mathrm{S}$ & Unknown & Unknown & Unknown & EPI_ISL_278020 \\
\hline A/Victoria/628/2017 & Victoria, Australia & 4 Aug & $\mathrm{S}$ & 90 & Male & Inpatient & EPI_ISL_277968 \\
\hline A/Victoria/2069/2017 & Victoria, Australia & 4 Aug & D & 57 & Male & Unknown & EPI_ISL_277965 \\
\hline A/Brisbane/1017/2017 & Queensland, Australia & 7 Aug & $\mathrm{S}$ & 31 & Female & Outpatient & EPI_ISL_277915 \\
\hline A/Sydney/1101/2017 & New South Wales, Australia & 9 Aug & $\mathrm{S}$ & 84 & Female & Unknown & EPI_ISL_283125 \\
\hline A/Sydney/1079/2017 & New South Wales, Australia & 9 Aug & $\mathrm{S}$ & 30 & Male & Unknown & EPI_ISL_277907 \\
\hline A/Victoria/653/2017 & Victoria, Australia & 10 Aug & $\mathrm{S}$ & 23 & Female & Outpatient & EPI_ISL_277940 \\
\hline A/Victoria/655/2017 & Victoria, Australia & 10 Aug & $\mathrm{S}$ & 82 & Male & Outpatient & EPI_ISL_277969 \\
\hline A/Victoria/624/2017 & Victoria, Australia & 11 Aug & $\mathrm{S}$ & 82 & Male & Inpatient & EPI_ISL_277922 \\
\hline A/Brisbane/140/2017 & Queensland, Australia & 22 Aug & $\mathrm{s}$ & 2 months & Female & Outpatient & EPI_ISL_283124 \\
\hline A/Darwin/1016/2017 & Northern Territory, Australia & 31 Aug & $\mathrm{S}$ & 42 & Male & Unknown & EPI_ISL_283121 \\
\hline A/Victoria/708/2017 & Victoria, Australia & 2 Sep & $\mathrm{D}$ & 8 & Female & Outpatient & EPI_ISL_283122 \\
\hline A/Victoria/697/2017 & Victoria, Australia & 2 Sep & $S$ & 77 & Male & Inpatient & EPI_ISL_283119 \\
\hline A/Victoria/856/2017 & Victoria, Australia & 18 Sep & $\mathrm{D}$ & 9 & Female & Unknown & Poor sequence quality \\
\hline A/Victoria/211/2017 & Victoria, Australia & 19 Sep & $\mathrm{s}$ & 68 & Male & Deceased & EPI_ISL_283123 \\
\hline A/Victoria/872/2017 & Victoria, Australia & 26 Sep & $\mathrm{S}$ & 58 & Female & Unknown & EPI_ISL_283120 \\
\hline
\end{tabular}

The spread of $M_{2} \mathrm{~N}_{31}$ viruses in the early $2000 \mathrm{~s}$ was thought to be due to linkage to advantageous substitutions elsewhere in the virus, in a process referred to as genetic 'hitch-hiking', and not related to adamantane-induced selection pressure [17]. Even though the $\mathrm{A}\left(\mathrm{H}_{3} \mathrm{~N}_{2}\right)$ virus has continued to undergo substantial antigenic and genetic evolution over the last decade, the $M_{2} N_{31}$ residue has remained almost completely fixed, suggesting that during that time it contributed to viral fitness. However, the recent detection of $\mathrm{M}_{2}$ S31 and D31 viruses in Australia suggests that the importance of the $M_{2} N_{31}$ residue in viral fitness may no longer be as strong as it was. We encourage surveillance laboratories, where possible, to conduct $\mathrm{M}_{2}$ sequencing of $\mathrm{A}\left(\mathrm{H}_{3} \mathrm{~N}_{2}\right)$ viruses during the upcoming 2017/18 northern hemisphere influenza season to see if the $M_{2} S_{31}$ or $D_{31}$ viruses begin to circulate in greater numbers globally.

In the seminal publication by Bright et al. on the emergence of the S31N variant in the early 2000s [4], the authors stated that 'further genetic and antigenic evolution of influenza $A\left(\mathrm{H}_{3} \mathrm{~N}_{2}\right)$ viruses resulting in the disappearance of the $S_{31} \mathrm{~N}$ mutation and reversion back to the drug sensitive phenotype should not be excluded'. It may be that the M2 S31 viruses detected in Australasia in 2017 could be the progenitors for a reversion back to more widely circulating adamantane-sensitive $A\left(\mathrm{H}_{3} \mathrm{~N}_{2}\right)$ viruses, some 12 years after the resistant strain emerged and then dominated globally. If this were the case, it would revive the option of using adamantanes to treat $\mathrm{A}\left(\mathrm{H}_{3} \mathrm{~N}_{2}\right)$ virus infections and improve the opportunities for using these drugs in combination with other antivirals [18].

\section{Acknowledgements}

The authors wish to acknowledge the contribution of colleagues in the World Health Organization (WHO) Collaborating Centre for Reference and Research on Influenza, Melbourne for conducting virus isolation and to the laboratories in the WHO Global Influenza Surveillance and Response System (GISRS) for the submission of influenza specimens or isolates to the Collaborating Centre. The authors also acknowledge the originating and submitting laboratories that provided sequences to GISAID's EpiFlu ${ }^{\mathrm{TM}}$ Data base which were used to calculate the global frequencies of $A\left(\mathrm{H}_{3} \mathrm{~N}_{2}\right)$ viruses with different amino acid residues of at position 31 of the M2 (www.gisaid.org). The WHO Collaborating Centre for Reference and Research on Influenza is supported by the Australian Government Department of Health.

\section{Conflict of interest}

None declared.

\section{Authors' contributions}

Y-MD, MK and NK conducted the genetic and phylogenetic analysis. SS conducted epidemiological analysis. AH drafted 
the manuscript. Y-MD, MK, NK, SS, KS, IB and AH contributed to the design and interpretation of the results, reviewed the early draft and approved the final version.

\section{References}

1. Jefferson T, Deeks JJ, Demicheli V, Rivetti D, Rudin M. Amantadine and rimantadine for preventing and treating influenza A in adults. Cochrane Database Syst Rev. 2004; (3):CDo01169. PMID: 15266442

2. Hayden FG, Hay AJ. Emergence and transmission of influenza A viruses resistant to amantadine and rimantadine. Curr Top Microbiol Immunol. 1992;176:119-30. https://doi. org/10.1007/978-3-642-77011-1_8 PMID: 1600749

3. Ziegler T, Hemphill ML, Ziegler ML, Perez-Oronoz G, Klimov Al, Hampson AW, et al. Low incidence of rimantadine resistance in field isolates of influenza A viruses. J Infect Dis. 1999;180(4):935-9. https://doi.org/10.1086/314994 PMID: 10479115

4. Bright RA, Medina MJ, Xu X, Perez-Oronoz G, Wallis TR, Davis $X M$, et al. Incidence of adamantane resistance among influenza A ( $\left.\mathrm{H}_{3} \mathrm{~N}_{2}\right)$ viruses isolated worldwide from 1994 to 2005: a cause for concern. Lancet. 2005;366(9492):1175-81. https:// doi.org/10.1016/So140-6736(05)67338-2 PMID: 16198766

5. Bright RA, Shay DK, Shu B, Cox NJ, Klimov Al. Adamantane resistance among influenza $A$ viruses isolated early during the 2005-2006 influenza season in the United States. JAMA. 2006;295(8):891-4. https://doi.org/10.1001/ jama.295.8.joc60020 PMID: 16456087

6. Deng YM, Spirason N, Iannello P, Jelley L, Lau H, Barr IG. A simplified Sanger sequencing method for full genome sequencing of multiple subtypes of human influenza $A$ viruses. J Clin Virol. 2015;68:43-8. https://doi.org/10.1016/j. jcv.2015.04.019 PMID: 26071334

7. Zhou B, Deng YM, Barnes JR, Sessions O, Chou TW, Wilson $M$, et al. Multiplex RT-PCR for Simultaneous Surveillance of Influenza A and B Viruses. J Clin Microbiol. 2017 Oct 4. pii: JCM.00957-17. doi: https://doi.org/10.1128/JCM.00957-17 . PMID: 28978683. [Epub ahead of print].

8. Deng YM, Caldwell N, Barr IG. Rapid detection and subtyping of human influenza $A$ viruses and reassortants by pyrosequencing. PLoS One. 2011;6(8):e23400. https://doi. org/10.1371/journal.pone.0023400 PMID: 21886790

9. Zaraket $\mathrm{H}$, Kondo H, Hibino A, Yagami R, Odagiri T, Takemae $\mathrm{N}$, et al. Japanese Influenza Collaborative Study Group. Full Genome Characterization of Human Influenza A/H3 $\mathrm{N}_{2}$ Isolates from Asian Countries Reveals a Rare Amantadine ResistanceConferring Mutation and Novel PB1-F2 Polymorphisms. Front Microbiol. 2016;7:262. https://doi.org/10.3389/ fmicb.2016.00262 PMID: 27014195

10. Mast EE, Harmon MW, Gravenstein S, Wu SP, Arden NH, Circo $\mathrm{R}$, et al. Emergence and possible transmission of amantadineresistant viruses during nursing home outbreaks of influenza A (H3N2). Am J Epidemiol. 1991;134(9):988-97. https://doi. org/10.1093/oxfordjournals.aje.a116184 PMID: 1951297

11. Degelau J, Somani SK, Cooper SL, Guay DR, Crossley KB Amantadine-resistant influenza A in a nursing facility. Arch Intern Med. 1992;152(2):390-2. https://doi.org/10.1001/ archinte.1992.00400140128027 PMID: 1739371

12. Hayden FG, Belshe RB, Clover RD, Hay AJ, Oakes MG, Soo W. Emergence and apparent transmission of rimantadine-resistant influenza A virus in families. N Engl J Med. 1989;321(25):1696 702. https://doi.org/10.1056/NEJM198912213212502 PMID: 2687687

13. Houck P, Hemphill M, LaCroix S, Hirsh D, Cox N. Amantadine-resistant influenza $A$ in nursing homes. Identification of a resistant virus prior to drug use. Arch Intern Med. 1995;155(5):533-7. https://doi.org/10.1001/ archinte.1995.00430050113012 PMID: 7864709

14. Hall CB, Dolin R, Gala CL, Markovitz DM, Zhang YQ, Madore $\mathrm{PH}$, et al. Children with influenza A infection: treatment with rimantadine. Pediatrics. 1987;80(2):275-82. PMID: 3302925

15. Barr IG, Hurt AC, Deed N, Iannello P, Tomasov C, Komadina $N$. The emergence of adamantane resistance in influenza $\mathrm{A}\left(\mathrm{H}_{1}\right)$ viruses in Australia and regionally in 2006. Antiviral Res. 2007;75(2):173-6. https://doi.org/10.1016/j. antiviral.2007.01.006 PMID: 17350111

16. Barr IG, Deng YM, lannello P, Hurt AC, Komadina N. Adamantane resistance in influenza $A\left(\mathrm{H}_{1}\right)$ viruses increased in 2007 in South East Asia but decreased in Australia and some other countries. Antiviral Res. 2008;80(2):200-5. https://doi. org/10.1016/j.antiviral.2008.06.008 PMID: 18611414

17. Simonsen L, Viboud C, Grenfell BT, Dushoff J, Jennings L, Smit $M$, et al. The genesis and spread of reassortment human influenza $\mathrm{A} / \mathrm{H}_{3} \mathrm{~N}_{2}$ viruses conferring adamantane resistance. Mol Biol Evol. 2007;24(8):1811-20. https://doi.org/10.1093/ molbev/msm103 PMID: 17522084

18. Beigel JH, Bao Y, Beeler J, Manosuthi W, Slandzicki A, Dar $\mathrm{SM}$, et al. Oseltamivir, amantadine, and ribavirin combination antiviral therapy versus oseltamivir monotherapy for the treatment of influenza: a multicentre, double-blind, randomised phase 2 trial. Lancet Infect Dis. 2017 Sep 22. pii: S1473-3099(17)30476-0. doi: https://doi.org/10.1016/S14733099(17)30476-0 . [Epub ahead of print]. PMID: 28958678.

\section{License and copyright}

This is an open-access article distributed under the terms of the Creative Commons Attribution (CC BY 4.0) Licence. You may share and adapt the material, but must give appropriate credit to the source, provide a link to the licence, and indicate if changes were made.

This article is copyright of the authors, 2017. 